Journal of Economics and Behavioral Studies

Vol. 6, No. 1, pp. 44-67, Jan 2014 (ISSN: 2220-6140)

\title{
Impact of Shocks to Public Debt and Government Expenditure on Human Capital and Growth in Developing Countries
}

\author{
Grace G. Kgakge-Tabengwa \\ Botswana Institute for Development Policy Analysis, Botswana \\ gkgakge@bidpa.bw
}

\begin{abstract}
This paper examines the implications of shocks to public debt and government expenditure on the development of human capital and growth within a model that explicitly recognizes the role of fiscal constraints through introducing the government budget constraint for a set of selected developing countries ${ }^{1}$ from 1980-2013. This is mainly to capture fiscal challenges facing developing countries in developing human capital which is fundamental for sustainable growth. The dynamics of our model results reveal that high stocks of public debt, beyond the 30-40\% debt/GDP threshold, depress the effect of human capital on output growth through limiting government expenditure resources available for developing human capital. Although we find that government expenditure has a positive role to play in developing human capital, sustainability becomes questionable particularly for countries where there are fiscal constraints. We conclude that developing countries which face fiscal challenges such as high public debt and poor revenue prospects to back government expenditure sustainably, cannot solely develop human capital based on the strength of their domestic resources, underscoring the need for specific supportive global fund for human capital development. The key policy implication calls for public debt management strategies and efficient government expenditure management frameworks supported by sustainable revenue prospects to provide fiscal sustenance impetus to enhance the growth process in developing countries.
\end{abstract}

Keywords: Human Capital, Growth, Government Budget Constraint, Developing Countries

\section{Introduction}

Developing countries are encouraged to prioritize human capital improvements as part of meeting the Millennium Development Goals (MDGs), attaining productivity and competitiveness through efficiency gains from knowledge accumulation. However, the fiscal sustainability of such policy proposals for developing human capital remains an issue that requires further research. The recent financial and economic crises of $2007 / 08$ and its impact on economic growth and development particularly in developing countries is indicative of how huge public debts and fragile fiscal positions can slow the growth process globally. For developing countries, while growth prospects have become weaker following shocks to the fiscal stance and government expenditure potential, a key question for policy is how shocks to public debt and government expenditure actually impact on human capital development since it is a central aspect to the growth and development agenda of developing countries. Human capital development is cited as a key factor that can transform developing countries growth prospects through efficiency, competiveness and contributing to attracting foreign direct investment inflow where expertise of skills is key (World bank, 2011). The upshot of the analysis from this paper may be that because of major gaps in human capital levels, some developing countries may be unable to close these gaps within reasonable time on the strength of their domestic resources. This will have an impact on the attainment of key developmental goals at the national level and in meeting key goals such as those of the MDGs. Further, few studies integrate growth models with the GBC despite the fiscal challenges facing developing countries in prioritizing human capital and sustainable growth. A meaningful policy strategy on human capital development in developing countries should be guided by research and analysis on the implications of public debt and government expenditure changes to the growth path. The importance of introducing the GBC in growth models has been highlighted by Turnovsky (1975)

\footnotetext{
${ }^{1}$ The set of selected developing countries includes: Botswana, South Africa, Malawi, Zambia, Kenya, Uganda, Tanzania, Cote d'Ivore, Ghana and Nigeria.
} 
and Kneller et al. (1999). They posit that it is important to capture the variables that enter the government budget constraint for a meaningful analysis of the long run growth effects of fiscal policy.

Sachs (1989) outlines in great detail the nature of the debt crisis facing many small open economies with serious difficulties in repaying debt, or in many cases even the interest on the debt. Economists argue that high debt makes it more difficult for countries to achieve the MDGs since the high debt and debt service absorbs resources that could be used for essential spending on poverty reduction, and diverts resources away from public investment on sectors such as education and health (Patillo et al., 2004). Consequently, many developing countries face unsustainable fiscal options which negatively affect their growth potential. The paper therefore focuses specifically on analyzing the impact of shocks to the public debt and government expenditure on human capital development which remains fundamental to unlocking the growth potential of many developing countries. The analysis considers fiscal challenges facing developing countries in developing human capital within a growth framework that captures the government budget constraint (GBC). While the growth implications of human capital have been analyzed to a considerable extent in the past (for example, Romer, 1990; Barro, 1990; Barro \& Sala -i-Martin, 1995; Levine \& Renelt, 1992; Mankiw, Weil \& Romer, $1992)^{2}$ the role of human capital on growth within a framework that captures both components of human capital, health and education as well as the GBC still remain under explored with few studies focusing on developing countries with high debt problems and poor fiscal positions. Accordingly, there remains little by way of understanding the process by which fiscal dynamics shape the growth prospects of human capital for developing countries even lately in the advent of the global economic and financial crises. In this regard, this paper contributes to the research gap to ensure that policy on human capital is informed on how government expenditure and public debt shape human capital development prospects in the developing economy. The remainder of this paper is structured as follows: Section 2.0 summarizes the literature reviewed. Section 3.0 describes the model framework, the data and the selected sample. Section 4.0 discusses the results and findings while Section 5.0 draws the conclusions and implications.

\section{Literature Review}

The role of human capital in the process of development has received much attention in the growth literature in recent time. In the last 20 years the new endogenous growth theory has increasingly influenced the economic growth literature. This framework is based on a production function of the constant returns to scale with output being a function of capital, labour and human capital. It emphasizes the role played by human capital accumulation in boosting growth through stimulating technological creation and invention, eventually leading to increased productivity (Barro, 1990). The endogenous model by Romer (1990) assumes that the creation of new ideas is a direct function of human capital which manifests in the form of knowledge. As such, in modern growth theory, the accumulation of human capital is an important contributor to economic growth (Romer, 1990). The main advantage of the new growth theories is that they incorporate explanations for long run growth (human capital and technological growth) into the model. In this way it is theoretically possible to determine the importance for growth of technology and human capital accumulation. A number of crosscountry studies, Barro (1990), Romer (1990) Barro and Sala-i-Martin (1995) have extensively explored whether the attainment of education can contribute significantly to the generation of overall output in economy. The analysis uses various indicators of education to assess the role of human capital on growth. These include indicators such as enrollment ratios, average years of schooling and adult literacy rates. Mankiw, Romer \& Weil (1992), Caselli, Esquivel \& Lefort (1996), Easterly \& Levine (1992), Klenow \& Rodriguez (1997), Barro (1991), Benhabib \& Spiegel (1997), Barro \& Sala-i-Martin (1995), Sala-i-Martin (1997), and many others find schooling to be positively correlated with the growth rate of per capita GDP across countries. Barro and Sala-i-Martin (1995) employ data on years of schooling attainment in a country's working-age population to test the hypothesis that schooling promotes growth and find that growth is highly correlated with school enrollment. These studies, however, define human capital to constitute of education and do not include health as a component of human capital. This study therefore, includes health as a component of human capital.

\footnotetext{
${ }^{2}$ Caselli et al. (1996), Greiner, Semmler and Gong (2004)
} 
Also, although the new endogenous growth theory emphasizes the role of knowledge spillovers in macroeconomic growth, it tends to neglect the role of the government budget constraint. For example while in Barro (1990) the role of government spending is emphasized in the endogenous growth framework by including a variable for the government sector, the components of the government budget constraint are not captured. This has led to a wide number of studies such as those cited in the above only assessing the role of human capital as education without considering the role of fiscal dynamics by capturing all variables that enter the government budget constraint. The government budget constraint captures the fiscal resources in terms of revenues at the disposal of the government to pursue development projects and expenditures (Turnovsky, 1975). The constraint also features the use government revenues through government expenditure on various sectors of the economy and the debt repayments. Given that developing countries tend to have poor fiscal profiles due to the high debt burden which limit resource allocation and spending 3 , it is therefore important to capture the government budget constraint in the analytical frameworks to assess how fiscal dynamics shape human capital and growth. The literature analyzing the effects of fiscal policy on growth is also based on the theory of endogenous economic growth (Barro, 1990) where the impact of public expenditures on economic growth is formalized in a simple endogenous growth model following Barro (1990) and Barro and Sala-i-Martin (1995) where output is a function of technology, labour, the capital stock and government spending. Other than the literature ${ }^{4}$ which tests for the relationships between fiscal policy and growth following the work of King and Rebelo (1990), Easterly and Rebelo (1993), Kneller, Bleany and Gemmell (1999), there is no empirical evidence capturing both aspects of human capital (health and education) and their effects on growth in an integrated growth framework which also captures the fiscal policy implications by including the government budget constraint. Studies that capture the government budget constraint, although not focusing on the implications for human capital, include those of Christ (1979) and Christopher (1995) which test the empirical implications of the government budget constraint. Therefore, this paper will thus fill this gap in the literature.

One study that is of particular importance in our work which we draw from in the approach to setting up the dynamics of the model framework we develop is the recent study by Greiner, Semmler and Gong (2004) which capture the government budget constraint under different fiscal policy rules in assessing the role of human capital on growth for a set of developed countries. However, in this work, human capital is only identified as education compared to our work where human capital constitutes health and education. Later in Greiner (2008) in an assessment of human capital formation, public debt and economic growth, an endogenous growth model where human capital formation is the result of public education and the government finances expenditures in the schooling sector by the tax revenue and public deficit is presented. Also, the government sets the primary surplus such that it is a positive linear function of public debt which guarantees that public debt is sustainable. The paper analyzes the structure of the growth model and derives implications of public debt and carries out a sensitivity analysis of the dynamics of the model. Greiner (2008) finds that a loose fiscal policy, where the government does not pay great attention to stabilizing debt, does not permit sustained growth in the long-run, unless the government is a creditor. In this case, there is a crowding-out of private investment and sustained growth is not feasible, unless the government is a creditor and lends to the private sector, so that the latter can finance necessary investment On the other hand, if the government puts a large weight on debt stabilization and does not invest sufficiently in the formation of human capital, sustained growth is not possible either, unless the government is again a creditor. In this case, the government must use its wealth in order to finance necessary investment in the formation of human capital. In this study, it is found that a strong rise in the primary surplus as a reaction to higher public debt stabilizes the economy. Greiner argues that for certain values of the reaction coefficient, cyclical growth occurs. If the reaction coefficient is set to a larger value, the economy stabilizes and converges to the constant balanced growth rate, if the reaction coefficient is set to a lower value, the economy becomes unstable. This analysis highlights the role of public debt and fiscal policy in developing human capital. However, in this case also, human capital is identified as education.

Bose et al. (2003) examine the growth effects of government expenditure for a panel of thirty developing countries over the decades of the 1970s and 1980s, with a particular focus on sectoral expenditures using the

\footnotetext{
${ }^{3}$ Clements e.t.al (2003)

${ }^{4}$ Kneller R, Bleaney and Gemmell (1999), Easterly and Rebelo (1993), Cashin (1995), Barro (1990).
} 
seemingly unrelated regressions (SURE) method. Compared to other previous works which do not recognize the role of the budget constraint, the analysis conducted by Bose et al. (2003) improves on previous research on this topic by explicitly recognizing the role of the government budget constraint and the possible biases arising from omitted variables. The study finds that the share of government capital expenditure in GDP is positively and significantly correlated with economic growth, but current expenditure is insignificant. The share of government capital expenditure in GDP is positively and significantly correlated with economic growth, while the growth effect of current expenditure is insignificant for the group of countries. At the sectoral level, government investment and total expenditures in education are the only outlays that remain significantly associated with growth throughout the analysis. The study finds that the private investment share of GDP is associated with economic growth in a significant and positive manner and there is strong evidence that a government budget deficit gives rise to adverse growth effects. Aizenman, Kletzer and Pinto (2007) analyze the impact of limited tax and debt capacity on growth. The study evaluates optimal public investment and fiscal policy for countries characterized by limited tax and debt capacities. The study adopts a non stochastic CRS endogenous growth model where public expenditure is an input in the production process, in countries where distortions and limited enforceability result in limited fiscal capacities, as captured by a maximal effective tax rate. The study finds that although the flow of public expenditure raises productivity, government should not borrow to finance it as the resulting increase in public debt would lower welfare and the growth rate. For countries with outstanding public debt, the optimal fiscal policy should keep the debt-to-GDP ratio constant in the economy with or without a binding constraint on tax revenues as a share of GDP. The analysis shows that the effects of debt limits on economic growth depend on the nature of the externality associated with public goods spending. Aizeman et al. (2007) conclude that higher debt is associated with lower long-run growth rates which are reached in finite time in the model economy. Also, a country with a lower debt-to-GDP ratio will have a higher balanced growth rate than a country with identical characteristics and higher debt.

The empirical research on how the stock of debt affects growth provides mixed evidence. Some studies find a negative impact of debt on growth when the debt ratio reaches a certain threshold. These studies include those of Clements et al. (2003) and Pattillo et al. (2002). The studies emphasize the crowding out effects on a stock of debt particularly when it exceeds $60 \%$ of GDP. They also note that the high stock of debt takes away resources that can be allocated for other development initiatives. Other studies that have found empirical support for the adverse effects of the public debt on growth and development include those by Bigsten et al. (2001), Chowdhury (2001) and Ebaldawi et al. (1997). These are important for this research where the analysis gives an assessment of the possible impact of the public debt on human capital development, mainly on health and education. In summary, while consensus exists on the positive role of human capital to growth, it is clear that in a number of studies ${ }^{5}$ quantifying the contribution of human capital to growth, only education indicators are used to define human capital. There is therefore a need to re-examine the growth effects of human capital on growth where human capital is determined by both health and education. Also, it is important that the role of health and education are considered as the main drivers of labour effectiveness. Human capital is a multifaceted concept which comprises various types of investments in people. Its definition has evolved over years of research on it. Although, initially it was simply considered as skills and knowledge acquired by people, Strauss and Thomas (1998) have expanded it to incorporate individual competencies, non-market activities, innate abilities, and individual attributes that facilitate the creation of social, personal and economic wellbeing as well. It is against this backdrop that the paper conducts an empirical examination of the two most important indicators of human capital, health and education and further includes the government budget constraint to examine how the public debt and government expenditure changes impact on human capital development and growth.

The Model Framework: The theoretical framework adopted follows the endogenous growth model of Romer (1990) but modified to include health and education as components of human capital and the government budget constraint. The GBC captures key fiscal components of government spending, revenue factors as well as the debt accumulated and its service which are relevant for the fiscal profile of the developing countries. According to Blinder and Solow (1973) and Christ (1968), the GBC introduces a

\footnotetext{
${ }^{5}$ Refer to studies by Mankiw, Romer and Weil (1992), Caselli, Esquivel and Lefort (1999); Easterly and Levine (1992), Barro (1991) Benhabib and Spiegel (1997), Barro and Sala-i-Martin (1995).
} 
dynamic system to an otherwise static system which allows an assessment of the long run growth dynamics. We assume an economy composed of three sectors: the household sector, the productive sector and the government sector. The model assumes one decision variable, consumption and two state variables, public capital stock and public debt. In line with Barro (1990), we integrate the role of government expenditure within the growth model to assess the effects of government expenditure on human capital and output per capita. The core equations and the structural relationships of the framework adopted for analysis is outlined and explained in the following equations in each of the three sectors.

The Productive Sector: In Equation (1), the production function is modified following Romer (1990). We assume that output per capita, $\tilde{Y}_{t}$ is a function of the proportion $\omega_{y}$, of the aggregate capital stock per capita $\widetilde{K}_{t}$, used in the production of output. $A_{t}$ is the technology or innovations used in the production of output. The role of government expenditure $G$ on production is introduced according to Barro (1990) and in our model, $1-v_{e}-v_{h}$ is the proportion of government spending on other sectors besides the health and education sectors. Government expenditure on health and education enters the production function through equations (3) and (4) which show the dependency between health, education, the physical capital stock and government expenditure.

$$
\begin{aligned}
& \hat{Y}=A_{t}^{1-\propto}\left(\omega_{y} \widehat{K}_{t}\right)^{\propto}\left(\left(1-v_{e}-v_{h}\right) G\right)^{\mu} \\
& A_{t}=A_{0 t} h_{t}^{\gamma} e_{t}^{1-\gamma} \\
& h_{t}=h_{0}\left(\omega_{h} k_{t}\right)^{\beta_{h}}\left(v_{h} g\right)^{\chi_{h}} \\
& e_{t}=e_{0}\left(\omega_{e} k_{t}\right)^{\beta_{e}}\left(v_{e} g\right)^{\chi_{e}}
\end{aligned}
$$

In Equation (2), we extend the Romer (1990) approach to include health, $h_{t}$, and education, $e_{t}$ as determinants of human capital which directly influence the effectiveness of labour $A_{t} . h_{t}$ and $e_{t}$ capture the indicators of health and education. According to Bloom et. al (2004), a healthy work force has positive implications for productivity since it is more productive, less absent from work and therefore contributes positively to growth of output. In this regard, we also argue for the introduction of health as a factor that influences the effectiveness of labour in the manner presented in equation (21). Education is also introduced as positively affecting labour effectiveness and productivity and thus having a positive effect on growth (Barro and Sala-i-Martin, (1995). Romer (1990) formalizes the argument that a more educated populace is better able to integrate new technologies. The index of the effectiveness of labour in our approach, taking into account the effects of health and education is thus given by Equation (2).

Equation (3) and (4) describes factors that influence health and education respectively. Changes in health depend on the proportion,$\omega_{h}$ of physical capital in the health sector and other factors, $h_{0}$, such as the quality of doctors and nurses. We assume that the physical capital stock in the health sector of a country has a positive role to play on health and its state. Similarly, in Equation (4), education in a particular country depends on $\omega_{e}$, the proportion of the physical capital stock in the education sector and $e_{0}$ are other factors which include the quality of teachers and education systems. In these equations, both education and health are also influenced by the proportion of government expenditure; $v_{h}$ and $v_{e}$ in the health and education sectors respectively. The introduction of government expenditure is assumed to positively affect health and education through availing resources for the continual operations of these sectors such that declining shares of government expenditure in these sectors may inhibit education and health development and therefore reduce growth prospects (Bose et al., 2003).

The four equations (1-4) describing the productive sector indicate the inter-relationships between health, education, technology or innovation, the physical capital stock, government expenditure and output. The interrelationships and interdependencies amongst these equations are shown through the substitution of the equations into the production function such that we have:

$$
\hat{Y}=A_{0}^{1-\alpha}\left(h_{t}^{\gamma} e_{t}^{1-\gamma}\right)^{1-\alpha}\left(\omega_{y} \widehat{K}_{t}\right)^{\alpha}\left(\left(1-v_{e}-v_{h}\right) G\right)^{\mu}
$$

It can be shown that the reduced form of equation (5) following the substitution process can be specified in per capita term in the following form

$$
y_{t}=\Omega_{0}^{1-\alpha} \omega k_{t}^{\theta} v \phi^{\mu} g
$$


where:

$\Omega=h_{0}^{\gamma} e_{0}^{1-\gamma}$,

$\omega=\omega_{h}^{\beta_{h} \gamma(1-\alpha)} \omega_{e}^{\beta_{e}(1-\gamma)(1-\alpha)} \omega_{y}{ }^{\alpha}$

$\theta=\alpha+\beta_{h} \gamma(1-\alpha)+\beta_{e}(1-\gamma)(1-\alpha)$

$g=g^{\chi_{h} \gamma(1-\alpha)} g^{\chi_{e}(1-\gamma)(1-\alpha)} g^{\mu} \quad 6$

$\phi=\left(1-v_{e}-v_{h}\right)$ and

$v=v_{h} \chi_{h} \gamma(1-\alpha) v_{e} \chi_{e}(1-\gamma)(1-\alpha)$

The interrelationships among the system of equation posit a positive role of the physical capital stock and government spending on health, education and growth. An improvement in health and education positively effects labour effectiveness. Since the effectiveness of labour is a component of output as indicated by the adopted production function, its improvement through enhanced health and education impacts positively on output.

The Household Sector: We assume that a representative household maximizes a discounted stream of utilities arising from consumption $c_{t}$ such that:

$$
U\left(c_{t}\right)=\int_{0}^{\infty} e^{(\varphi(1-\sigma)-\rho) t} \frac{\check{C}^{1-\sigma}}{1-\sigma} d t
$$

$\sigma$ is the elasticity of marginal utility with respect to consumption and $\rho$ is a constant discount factor calibrated at 0.1 for all the countries. $u(c)$ is the utility function which is strictly increasing in $c$ and concave; $u^{\prime}(c)>0$ and $u^{\prime \prime}<0$ (Greiner et al., 2004).

Changes in the capital stock, $K$ are influenced by the previous capital which depreciates over time at the rate $\delta$. Output changes, $Y$ have a positive effect on physical capital, while consumption, $c$ reduces the rate of capital accumulation. Increasing government expenditure, $g$ reduces the rate of capital accumulation while a rising growth rate of debt service negatively effects capital accumulation. Increasing government spending will raise the debt and debt weighs on the accumulation of capital which reduces growth. A rising expenditure on health and education implies that the government has to raise taxes to reverse the negative growth effect that arises from increased spending. The specification adopted for the rate of growth of capital accumulation takes the form:

$$
\dot{k}_{t}=y_{t}-c_{t}-g_{t}-r_{t} b_{t}-(\delta+n+\psi) k_{t}
$$

Substitution for $y_{t}$ and the marginal productivity of capital, $r_{t}$ implies that the reduced form of the capital accumulation constraint per unit of effective labour takes the form:

$\dot{k}_{t}=\Omega_{0}^{1-\alpha} \omega k_{t}^{\theta} \phi^{\mu} g-c_{t}-g_{t}-\Omega_{0}^{1-\alpha} \omega \theta k_{t}^{\theta-1} \phi^{\mu} g b_{t}-(\delta+n+\psi) k_{t}$

Where $b(t)$ is the public debt and $r_{t-1} b_{t-1}$ is the debt service. From Equation (9) changes in the per capita capital stock are negatively affected by the depreciation rate $\delta$ the growth rate of labour efficiency, $\psi$ and the growth rate of the labour force $n$. The per capita output positively influences the accumulation of capital while consumption per capita, c reduces the rate of capital accumulation.

The Government Sector: Christ (1967, 1968), Blinder and Solow (1973) and others have shown how the GBC imposes a dynamic structure on an otherwise static system. The reason for this is that the financing of any budget deficit or surplus must involve changes in the net claims of the private sector against the government, and these in turn lead to changes in the other endogenous variables. Hence the system can be in equilibrium only when the government's budget is balanced. The Blinder and Solow (1973) paper in particular, has shown how the method used by the government to finance its budget deficit has a crucial effect on both the stability of fiscal policy and the long-run impact of government expenditure on activity. Obstacles including the highly concentrated tax systems and expenditure rigidities complicate developing countries efforts to consolidate their fiscal positions. Some countries face considerable increases in government debt and hence, they are undergoing reforms to reduce the deficits through tax reform and reduced expenditure. Given the importance of the GBC for the growth dynamics of human capital, we assume a government that faces a

\footnotetext{
${ }^{6}$ The g's on the right hand side are the sub components from the optimization. Refer to appendix section to follow the differentiation stages.
} 
government budget constraint such that the growth in government debt, $\dot{b} . b_{t}$ depends on the debt service $r_{t} b_{t}$ of the existing debt with interest on debt, $r_{t}$ government expenditure, $\mathrm{g}$ less tax revenues, $\mathrm{t}$

$\dot{b}=g-t+(r-n-\varphi) b$

Since taxes are a proportion of income, equation (29) is re-written as:

$\dot{b}=g-\tau y+(r-n-\varphi) b$

and $\tau$ is the proportion of taxes in total income. Substituting for y and the marginal productivity of capital, we obtain the following government budget constraint in our framework:

$\dot{b}=g-\tau\left(\Omega_{0}^{1-\alpha} \omega k_{t}^{\theta} \phi^{\mu} g\right)+\left(\Omega_{0}^{1-\alpha} \omega \theta k^{\theta-1} \phi^{\mu} g-(n+\varphi) b\right.$

According to Clements et al. (2003) the debt stock and debt service, at least when they are at very high levels may hinder growth through distortions of private and public investment incentives. A high current debt may severely hamper future debt-servicing capacity because it might introduce the economy all kinds of disincentive effects to invest and adjust, resulting in a severe negative effect on future economic growth. This is the so called debt overhang hypothesis by (Pattillo et al., 2002; Chowdhury, 2004). This effect is usually linked to a high stock of debt. Sachs (1986) argues that in this situation the high stock of debt acts like a high marginal tax on investment. They suggest that the incentives for domestic firms or the debtor government to invest at home are distorted since any positive returns from investment projects are used for debt payments. Hence, the net present value of repayments increases.

The model is closed with a balanced budget rule to assess how the model behaves under a fiscal policy rule, the primary balanced budget rule such that: $g-\tau y=0$

This is contrary to the budgetary regime followed by the government where instruments (expenditure and taxes) ${ }^{7}$ are used to derive the government budgetary rule (Greiner et al., 2004). The budgetary rules adopted in the paper are essential to impose a constraint on the budgetary policy of government and for macroeconomic stability.

Dynamics of the Model ${ }^{8}$ : The dynamic behavior of our model which allows us to employ the simulations to determine the optimal growth path in the presence of binding constraints is derived using the Maximum Principle Approach for optimization according to Greiner, Semmler and Gong (2004). In the model we assume that a representative household maximizes a discounted stream of utilities arising from consumption $c_{t}$ such that:

$$
U\left(c_{t}\right)=\int_{0}^{\infty} e^{(\varphi(1-\sigma)-\rho) t} \frac{\check{C}^{1-\sigma}}{1-\sigma} d t
$$

subject to the capital accumulation and the debt constraint of the model:

$$
\begin{aligned}
& \dot{k}_{t}=\Omega_{0}^{1-\alpha} \omega k_{t}^{\theta} \phi^{\mu} g-c_{t}-g_{t}-\Omega_{0}^{1-\alpha} \omega \theta k_{t}^{\theta-1} \phi^{\mu} g b_{t}-(\delta+n+\psi) k_{t} \\
& \dot{b}=g-\tau\left(\Omega_{0}^{1-\alpha} \omega k_{t}^{\theta} \phi^{\mu} g\right)+\left(\Omega_{0}^{1-\alpha} \omega \theta k_{t}^{\theta-1} \phi^{\mu} g-(n+\varphi)\right) b_{t}
\end{aligned}
$$

The derivations of the first order conditions and dynamic system are detailed in the Appendix. There are three key dynamic processes that drive the system of the model together with the production function (equation 1 ), the effectiveness of labour equation (equation 2), and the health (equation 3) and education equation (equation4). The first is the path for the growth of the consumption per capita, the $\dot{c}$ function in equation 11 and the second is the path for the growth of capital accumulation $\dot{k}$ equation (9) and thirdly, the debt equation which constitutes the GBC. The dynamic equations interact the physical capital stock per capita with consumption, government expenditure, health and education as well as the growth of rates the physical capital stock, depreciation of the physical capital stock and labour. The reduced form of the equations for the dynamics of the model takes the form:

\footnotetext{
${ }^{7}$ See Greiner, Semmler and Gong (2004) for a discussion of the budgetary regimes introduced by Blinder and Solow (1973)

${ }^{8}$ In case equations do not display due to memory capacity for equations, refer to Appendix for a repeat of these equations (15-17)
} 


$$
\begin{aligned}
& \frac{\dot{c}}{c}=\frac{(1-\tau) \Omega_{0}{ }^{(1-\alpha)} \omega \theta k^{\theta-1} v \phi^{\mu} g-(\delta+n+\varphi)-\rho}{\sigma} \\
& \dot{k}=\Omega_{0}^{1-\alpha} \omega k^{\theta} v \phi^{\mu} g-c-g-\Omega_{0}^{1-\alpha} \omega \theta k^{\theta-1} v \phi^{\mu} g b-(\delta+n+\psi) k \\
& \dot{b}=g-\tau\left(\Omega_{0}^{1-\alpha} \omega k_{t}^{\theta} v \phi^{\mu} g\right)+\left(\Omega_{0}^{1-\alpha} \omega \theta k_{t}^{\theta-1} v \phi^{\mu} g-(n+\varphi)\right) b
\end{aligned}
$$

The dynamic system given by equation (19 - (21) leads to some dependencies between the rows of the Jacobian of the system, which allows us to examine the stability properties of the model and equilibrium solutions with phase diagrams following Romer (1990) on the basis of the sign structure of the Jacobian.

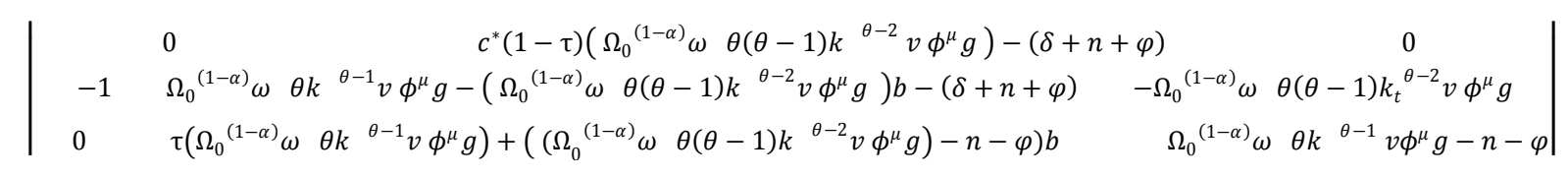

The system is tested for stability using the Routh-Hurwitz stability criterion which is a necessary (and frequently sufficient) method to establish the stability of a dynamic system of equations (Turnovsky, 1975). The criterion establishes a systematic way to show that the linearized equations of motion of a system have only stable solutions. It can be performed using either polynomial divisions or determinant calculus. For the a $3 \times 3$ matrix indicated above, and assuming that the matrix is given by $\mathrm{J}$ as below, the procedure followed to test the stability of the system for each country is given below:

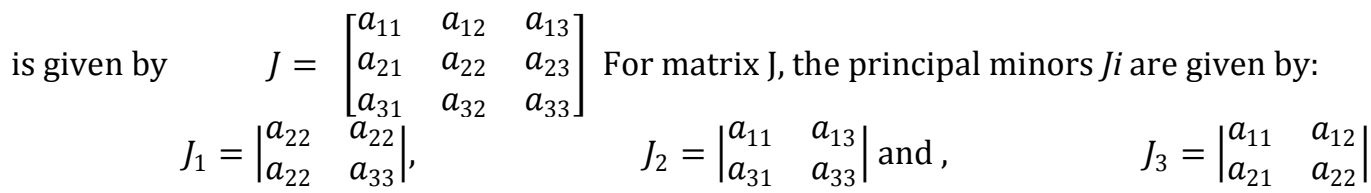

The Routh-Hurwitz necessary and sufficient condition for the stability of the system is expressed as:

- $\quad$ Trace $(\mathrm{J})<0$, where trace $(\mathrm{J})=a_{11}+a_{22}+a_{33}$

- $J_{1}+J_{2}+J_{3}>0$

- $\quad$ Det $\mathrm{J}<0$

- $\quad-\operatorname{trace}(J)\left(J_{1}+J_{2}+J_{3}\right)+|J|>0$

- $\quad$ Det $|J|=a_{11}\left|a_{22} a_{33}-a_{32} a_{33}\right|-a_{21}\left|a_{12} a_{33}-a_{32} a_{13}\right|+a_{31}\left|a_{12} a_{23}-a_{22} a_{13}\right|$

When these conditions are met for each of the dynamic system of equations, the simulations converge following the shocks. In the case where the stability criteria is not met, then the paths to convergence will either explode or be unstable and not return to stability.

\section{Empirical Estimation}

Data Description and Measurement: The analysis is conducted for a sample of selected African countries: Botswana, South Africa, Malawi, Zambia, Uganda, Kenya, Tanzania, Cote d'Ivore, Ghana and Nigeria, Ghana. The selection covers countries of various income, development levels and with differing debt/GDP profiles and offers a coverage of developing countries in Africa. Availability of data was also a key factor considered in sample selection. The data used is collected from the IMF/World Bank Statistics, the World Development Indicators (WDI) and the National Accounts of the respective countries. Data from the Human Development Indicators for various years is used to augment the data from the WDI on the education and health indicators. Table 1 below is a summary of the data used to estimate the parameters of the model for the selected countries.

Enrollment ratios are used to derive the education indicator which places more weight on higher education given that it plays more role in enhancing the effectiveness and productivity of labour with weights of $10 \%$ for primary enrollment, $40 \%$ for secondary enrollment and $50 \%$ to tertiary enrollment rates. This indicator captures higher education as possible to the Barro and Lee (1993) average years of schooling of people aged 
over 25 years in that less weight is given to lower education enrollment. Other studies use other indicators but these are not readily available in the set of countries chosen here for analysis. The life expectancy at birth indicator is also derived such it places more weight on the productive age bracket of the population. A human capital index derived as: Human capital index $x_{i}=h^{\gamma} \boldsymbol{e}^{\mathbf{1 - \gamma}}$ is used to address the interactions between health and education.

\section{Table 1: Description of the Data and Measurement}

\begin{tabular}{l}
\hline Variable \\
\hline$y_{t}=$ Output per capita \\
$k_{t}=$ Physical capital stock \\
$A_{t}=$ Innovation or technology \\
$g_{t}$ \\
$b_{t}$ \\
$\omega_{y}=$ Proportion of physical capital \\
stock used in the production of \\
output \\
$h_{t}=$ Health indicator
\end{tabular}

$\omega_{h}, \omega_{e}=$ proportion of physical capital stock in the health sector and educatotion sector respectively $e_{t}=$ Education indicator

$v_{h}, v_{e}$ Measurement

Real gross domestic product per capita (2000 US\$)

Derived using inventory perpetual method (2000 US\$)

Solow residual from estimated production function

Government expenditure per capita (2000 US\$)

Public debt per capita

Proportion of physical stock used for production $\left(1-\omega_{h}-\omega_{e}\right)$

Generated from life expectancy at birth. To capture productive age group , alternative indicator is derived from life expectancy as $h_{t}=\left(\frac{\text { Lifeexpectancy }}{65 y \text { rs }}\right) * 100$

Derived from physical stock series using average share of physical stock in the health sector and education sector

Generated from gross enrolment rates for primary, secondary and tertiary education. To capture the effect of higher education average enrollment rates computed place higher weight on higher education $e_{t}=0.1$ (Primary $)+0.4$ (Secondary $)+$ 0.5 (tertiary)

Share of government expenditure in the health and education sector.

The physical capital stock series is derived for each country using the inventory perpetual method following Liman and Miller (2004). $K_{t}=\sum_{i=9}^{t=1}(1-\delta)^{i} I_{t-1}+K_{0}(1-\delta)^{t}$ where $I_{t-1}$ is the previous period's gross fixed capital formation for each country. A constant rate of depreciation of 7 percent is used in line with Benhabib and Spiegel (1997) and King and Rebelo (1990).

Estimated and Calibrated Parameters of the Model: The parameters estimated and calibrated are utilized in the dynamic simulations which are key to the assessment of the implications of shocks to the public debt and government expenditure reported in the following subsections (4.3). The non-linear estimation technique which does not make any strong assumptions about the data set and the errors is used for estimation. This procedure allows for possibilities of nonlinearities in the parameters of the model. We correct for serial correlation and include time fixed dummies to capture the effects of other factors and outlier observations which may be due to structural changes which may bias the results.

The parameters show a positive role for human capital on growth performance in the set of countries. Improving human capital will thus contribute significantly to growth in this is more pronounced for countries such as Botswana and South Africa where the impact effect on gdp is estimated at more than $20 \%$.the components of human capital, health $\beta_{h}$ and education $\beta_{e}$ are found to be positively play a role in enhancing labour effectiveness. The finding is key in ensuring that strategies for enhancing productivity and efficiency target both health and education since they positively contribute to labour effectiveness. We find that the physical capital stock is a key factor in the development of health and education as shown by the positively significant $\propto$ coefficient across all countries as reported in the table. Hence focus on the development of the requisite infrastructure in the health and educations sectors remains fundamental in policies for human capital development in developing countries. The convergence parameter $\theta$ at below 1 for all countries shows convergence of parameters in the model and existence of stability with consistent parameter estimates. The diagnostic statistics and endogeneity tests are summarized in the appendix. Other parameters are calibrated where the availability of disaggregated data on government expenditure was not available to allow direct 
estimation of those parameters, for example in the cases of $\mu$, based on Barro (1990), Bose et al. (2003) while $v_{h} \quad v_{e} \quad$ calibrated for each country based on the proportions of expenditure in the health and education sectors respectively. The calibration of $\chi_{h} \quad \chi_{e}$ is based on government spending and infrastructure on the health and education sectors (Bose et al., 2003). The rate of depreciation is calibrated at $7 \%$ following Benhabib and Spiegel (1997) and King and Rebelo (1990). While the time rate of preference and discount factor are calibrated at $0.1 \%$ and $0.9 \%$ in line with Romer (1990).

Table 2: Calibrated and Estimated Parameters (standard errors in parenthesis)

\begin{tabular}{|c|c|c|c|c|c|c|c|c|c|c|}
\hline $\begin{array}{l}\text { Estimated } \\
\text { Parameters }\end{array}$ & Botswana & $\begin{array}{l}\text { South } \\
\text { Africa }\end{array}$ & Zambia & Kenya & Nigeria & $\begin{array}{l}\text { Cote } \\
\text { d'Ivore } \\
\end{array}$ & Malawi & Tanzania & Uganda & Ghana \\
\hline$\alpha$ & $\begin{array}{l}0.45 \\
(0.016)\end{array}$ & $\begin{array}{l}0.35 \\
(0.022)\end{array}$ & $\begin{array}{l}0.21^{*} \\
(0.013)\end{array}$ & $\begin{array}{l}0.33 \\
(0.010)\end{array}$ & $\begin{array}{l}0.36 \\
(0.026)\end{array}$ & $\begin{array}{l}0.26^{*} \\
(0.015)\end{array}$ & $\begin{array}{l}0.20^{*} \\
(0.035)\end{array}$ & $\begin{array}{l}0.25^{*} \\
(0.010)\end{array}$ & $\begin{array}{l}0.32 \\
(0.010)\end{array}$ & $\begin{array}{l}0.30 \\
(0.020)\end{array}$ \\
\hline$\gamma$ & $\begin{array}{l}0.52 \\
(0.046\end{array}$ & $\begin{array}{l}0.47 \\
(0.036)\end{array}$ & $\begin{array}{l}0.36 \\
(0.038)\end{array}$ & $\begin{array}{l}0.49 \\
(0.047)\end{array}$ & $\begin{array}{l}0.40 \\
(0.022)\end{array}$ & $\begin{array}{l}0.38 \\
(0.019)\end{array}$ & $\begin{array}{l}0.32 \\
(0.029)\end{array}$ & $\begin{array}{l}0.35 \\
(0.030)\end{array}$ & $\begin{array}{l}0.39 \\
(0.027)\end{array}$ & $\begin{array}{l}0.42 \\
(0.022)\end{array}$ \\
\hline$\beta_{h}$ & $\begin{array}{l}0.23 \\
(0.043)\end{array}$ & $\begin{array}{l}0.31 \\
(0.048)\end{array}$ & $\begin{array}{l}0.24 \\
(0.031)\end{array}$ & $\begin{array}{l}0.22 \\
(0.016)\end{array}$ & $\begin{array}{l}0.03^{* *} \\
(0.007)\end{array}$ & $\begin{array}{l}0.06^{* *} \\
(0.004)\end{array}$ & $\begin{array}{l}0.13^{* *} \\
(0.010)\end{array}$ & $\begin{array}{l}0.14^{* *} \\
(0.008)\end{array}$ & $\begin{array}{l}0.02^{* *} \\
(0.003)\end{array}$ & $\begin{array}{l}0.03^{* *} \\
(0.001)\end{array}$ \\
\hline$\beta_{e}$ & $\begin{array}{l}0.33 \\
(0.019)\end{array}$ & $\begin{array}{l}0.42 \\
(0.027)\end{array}$ & $\begin{array}{l}0.18^{* * *} \\
(0.025)\end{array}$ & $\begin{array}{l}0.34 \\
(0.027)\end{array}$ & $\begin{array}{l}0.30 \\
(0.015\end{array}$ & $\begin{array}{l}0.12^{* * *} \\
(0.009)\end{array}$ & $\begin{array}{l}0.29 \\
(0.056)\end{array}$ & $\begin{array}{l}0.39 \\
(0.017)\end{array}$ & $\begin{array}{l}0.49 \\
(0.016)\end{array}$ & $\begin{array}{l}0.21^{* * *} \\
(0.009)\end{array}$ \\
\hline \begin{tabular}{l}
\multicolumn{1}{c}{$\theta$} \\
Calibrated \\
Parameters
\end{tabular} & 0.603 & 0.555 & 0.369 & 0.522 & 0.402 & 0.415 & 0.391 & 0.477 & 0.529 & 0.394 \\
\hline $\begin{array}{l}\rho \\
\delta\end{array}$ & $\begin{array}{l}0.1 \\
0.07\end{array}$ & $\begin{array}{l}0.1 \\
0.07\end{array}$ & $\begin{array}{l}0.1 \\
0.07\end{array}$ & $\begin{array}{l}0.1 \\
0.07\end{array}$ & $\begin{array}{l}0.1 \\
0.07\end{array}$ & $\begin{array}{l}0.1 \\
0.07\end{array}$ & $\begin{array}{l}0.1 \\
0.07\end{array}$ & $\begin{array}{l}0.1 \\
0.07\end{array}$ & $\begin{array}{l}0.1 \\
0.07\end{array}$ & $\begin{array}{l}0.1 \\
0.07\end{array}$ \\
\hline$\sigma$ & 0.9 & 0.9 & 0.9 & 0.9 & 0.9 & 0.9 & 0.9 & 0.9 & 0.9 & 0.9 \\
\hline$\mu$ & 0.30 & 0.30 & 0.30 & 0.30 & 0.30 & 0.30 & 0.30 & 0.30 & 0.30 & 0.30 \\
\hline$v_{h}$ & 0.10 & 0.16 & 0.04 & 0.09 & 0.12 & 0.05 & 0.08 & 0.04 & 0.07 & 0.05 \\
\hline$v_{e}$ & 0.16 & 0.20 & 0.06 & 0.12 & 0.16 & 0.15 & 0.18 & 0.15 & 0.18 & 0.18 \\
\hline$\chi_{h}$ & 0.10 & 0.10 & 0.10 & 0.10 & 0.10 & 0.10 & 0.10 & 0.10 & 0.10 & 0.10 \\
\hline$\chi_{e}$ & 0.20 & 0.20 & 0.20 & 0.20 & 0.20 & 0.20 & 0.20 & 0.20 & 0.20 & 0.20 \\
\hline
\end{tabular}

Note: $*$ indicates countries with $\propto<0.30, * *$ where $\beta_{h}<0.20$ and $* * *$ where $\beta_{e}<0.30$. which are averages for these parameters. Diagnostic tests are provided in the summary table in the appendix and the test for endogeneity between health and education.

\section{Results Interpretation and Analysis}

Impact of Public Debt on Human Capital and Growth: We assess the implications of a 1\% increase (temporary and permanent shock) in the public debt on human capital development within the dynamic growth system. Considering the possible links and interactions between health and education, the impact of the shock on the public debt is also analyzed with the human capital index. The impact responses in the dynamic simulations are summarized in the impulse reaction functions showing the impact on output, government spending and the human capital index as given in Figures 1-2. In Figure 1-2, for each country, we report the response functions for the impact of the shock to public debt on output, government expenditure, deficit, health and education and the human capital index (the four small graphs in a row under each country) 
Figure 1: Impact of a Temporary Shock to the Public Debt under a Balanced Budget Fiscal Policy Rule

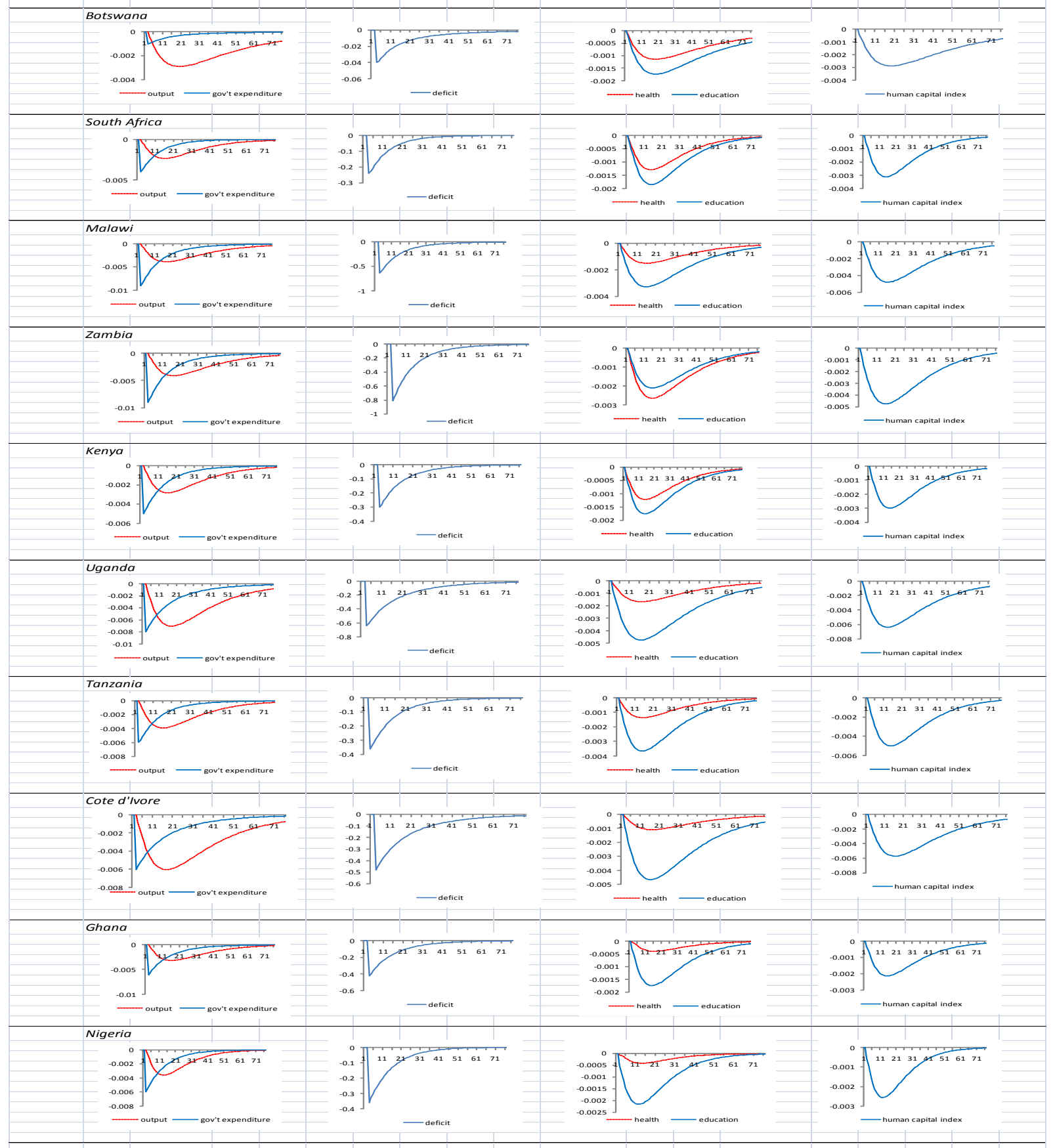


Figure 2: Impact of a 1\% Permanent Shock to the Public Debt under a Balanced Budget Fiscal Policy Rule

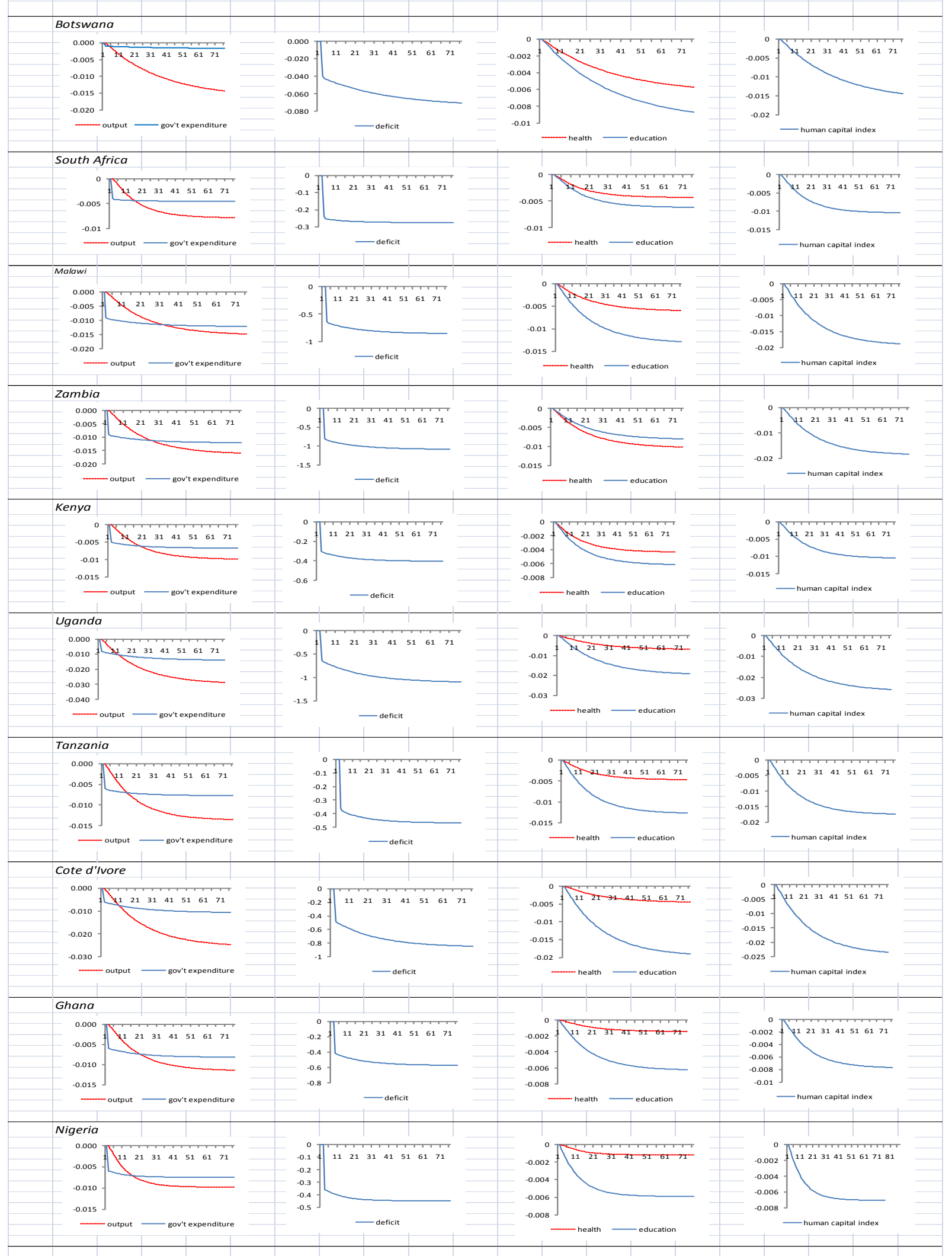


We find that, for all countries in general, an increase in the public debt leads to a decrease in human capital especially once the public debt goes beyond the 30-40\% debt/GDP threshold. There is, however, a variation on the magnitude of the impact on output, government expenditure, health, education, the deficit and government expenditure. The impact of the public debt on the human capital index is found to be negatively affected by the public debt in the selected countries. In all cases, it is clear that the impact of the public debt in the case of Botswana and South Africa where the public debt/GDP ratio has been maintained at levels below $40 \%$, the impact effect on human capital, the deficit and government spending is less pronounced. In other countries, however, where the debt to GDP ratio has exceeded $40 \%$ of GDP on average in the sample period of 1980-2010 (for example in countries such as Zambia, this has gone as high as 180\%), the impact of the debt is found to lead to significant declines in output, human capital and government expenditure while the deficit rises substantially.

For countries, where the public debt has exceeded $40 \%$ on average (with the exception of Botswana and South Africa) the impact of the public debt both on a temporary and permanent basis leads to significant major impacts on output, government expenditure and on human capital. This is observed in Zambia, Malawi, Tanzania, Uganda and Cote d'Ivore where some of these countries have been once classified in the category of the highly indebted poor countries (HIPC) at one point. The results for Kenya, Ghana and Nigeria, though also adversely affected by the public debt, the impact is found to be less severe when compared to that seen in the cases of Zambia, Cote d'Ivore, Malawi, Uganda and Tanzania. What is visible from the results of the analysis is that countries with a debt to GDP ratio of less than $40 \%$ such as Botswana and South Africa are less affected by public debt in developing human capital. This is evidenced by the smooth adjustment following the shock and the lesser adverse effect of the public debt compared to other countries.

Our results indicate that there is a certain level of the public debt/GDP ratio that affects growth and the development of human capital. This is clear from the results obtained in the case of Botswana where the public debt has consistently been maintained at lower levels of averaging less than $20 \%$ of GDP and less than $40 \%$ of GDP. Similar results on the impact of the public debt on human capital and growth are observed in the case of South Africa where the public debt averages about 30\% and in Kenya where the public debt GDP ratio stands at just about $40 \%$. For other countries where the public debt has exceeded $40 \%$, going over $60-70 \%$ of GDP in some years in the cases of Zambia, Malawi, and Cote d'Ivore, there is evidence that the high public debt has a significant impact on human capital and growth. Our results show that beyond a certain debt/GDP ratio threshold, which in this case is $40 \%$ and above, public debt adversely affects human capital development and growth. These findings are consistent with the literature results which show that beyond a certain threshold, debt is bad for growth and development (see for example findings by Bigsteien et al., 2001; Ebaldawi et al., 1997). A number of studies estimate this threshold at about 60\%, while Patillo et al. (2002) estimates it at 35$40 \%$ of GDP. In our study, we find that countries such as Botswana and South Africa, where the debt to GDP ratio has been consistently maintained at less than $40 \%$, debt does not significantly affect output. Following a shock to the public debt, the economy is able to recover its fundamentals with less volatility and smoothly in these countries where the debt/GDP ratio is lower. For countries where debt exceeds more than $40 \%$ threshold, there is volatility in the adjustment towards steady state following the shock. Also, the impact on output, health and education is negative and remains low and declining (long recovery period) for a long time.

This shows that such countries will not be able to pursue human capital development on the strength of their own domestic resources. Even with initiatives such as those by the IMF/World Bank on addressing the public debt, it remains critical to have a fund that specifically focuses on human capital development, mainly health and education given its importance in unlocking the potential for growth in the areas of efficiency, productivity, competiveness and foreign direct investment inflow leading to sustainable growth. Following the shock to the public debt, there is a pronounced fall in government spending and this shows that as government restrains its spending to maintain fiscal sustainability induced by the high public debt, this move takes away resources for the development of human capital. This results in declines in health and education which translates in to the fall in output. This shows that as the public debt takes away the resources and results in restrained public spending in the health and education. The adverse impact of the public debt on growth through a reduction in the resources available for developing human capital are somewhat consistent 
with the crowding out effects of the public debt and resources in line with Patillo et al. (2004) who also argue that a high public debt takes away and diverts resources for growth and development.

There is evidence of delayed lag effects on the effect of the public debt on the other variables of the model. This mainly on the length of time it takes for the effects of the public debt to take effect on government spending, health, education and output. There is a time lag on the impact of human capital on growth and on the feed through mechanism of the public debt and its impact on human capital and growth. When we used the human capital index, constituting of health and education to take care of the possible interaction between health and education, we find that the response of the human capital index to the shock to the public debt shows similar results in that the public debt negatively affects the index, similar to the impact effects found when health and education indicators are treated separately in the simulation. There is clear evidence of lag effects on the impact effects and transmission of health, education and impacts on output with the number of years varying across countries in the sample.

Impact of Government Spending on Human Capital and Growth: Figures 3-6 show the response of output and human capital following a shock to government expenditure. In Figure 3 and 4, we disaggregate government spending according to spending on the health and education sectors to assess the impact of a shock to government spending on health (education) while holding spending on education (health) constant. We specifically assess the impact of an increase in government spending (1\% increase in government spending on health, holding spending on education constant). The test is carried out this way considering the fact that it is not always possible for countries where resources are a constraint to raise development spending on all social sectors for example simultaneously on education and health. The competing priority sectors often put government under pressure to not to raise spending on many sectors at the same time but to prioritize sectors and commit resources where they are most needed in any budget period. Most countries, particularly lesser developed countries, are also not always in a position to raise government spending for a number of sectors at the same time. This is because of the resource constraints and also the competing priority sectors for government resources (Cashin, 1995). Similarly, in Figure 4, we conduct the simulations of shocks on government spending on education holding government spending on health constant.

To take into account the interactions between health and education, the human capital index is used to evaluate the impact of increasing government spending either on education or health where we assume we cannot explicitly separate health and education. The impact analysis is carried out using the temporary shock and a permanent shock with response function presented in Figures (5-6). A key aspect is the consideration that that government pursues a policy of developing human capital and commits resources to both health and education as human capital, and therefore assessing the implications of government expenditure increase on the two components of human capital, the public debt and output. In this case, the shock to government spending is on human capital index (total effect) compared to the previous case where the shock is on government spending on one component of human capital holding spending on the other component constant. 
Figure 3: Impact of a Temporary Shock to Government Spending on Health/ Education (holding one constant)

Impact of a Temporary Shock to Government Spending on Health (Education) holding Spending on Education (Health) Constant

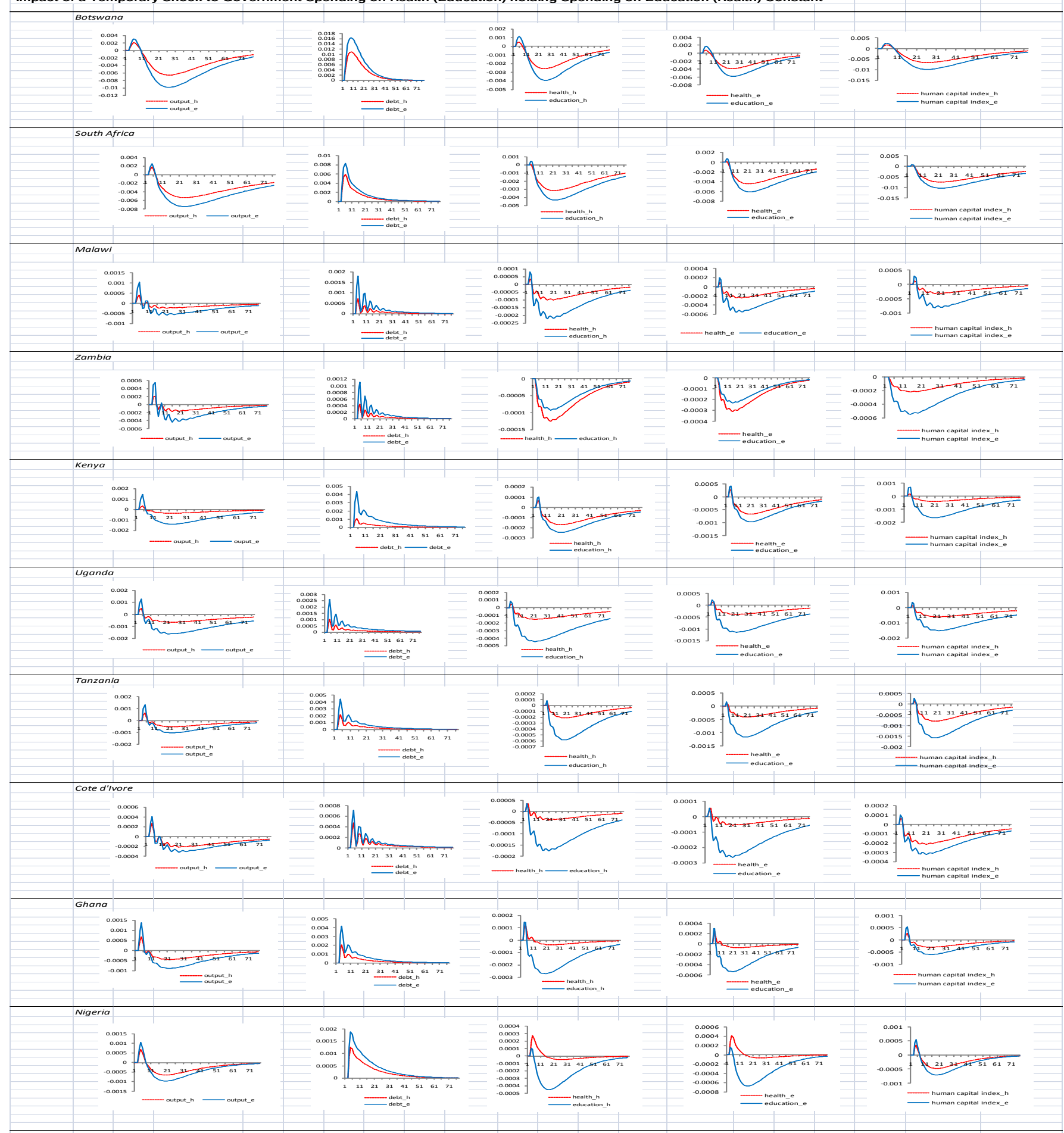


Figure 4: Impact of a 1\% permanent Shock to Government Spending on Health/Education (holding one constant)

Impact of a Permanent Shock to Government Spending on Health (Education) holding Spending on Education (Health) Constant

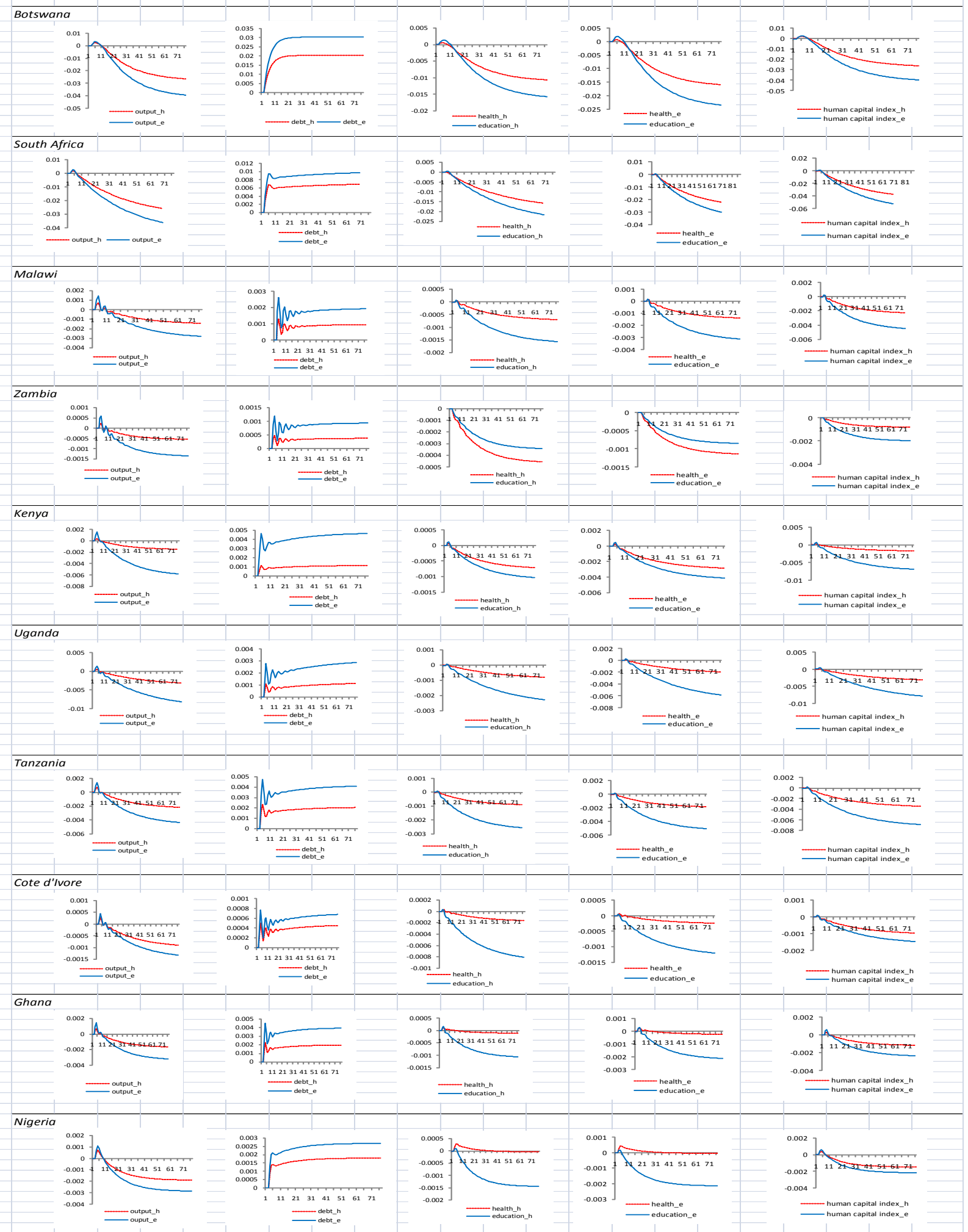


Figure 5: Impact of a Temporary Shock to Government Spending on Health and Education (total effect) Impact of a Temporary Shock to Government Spending on Human Capital

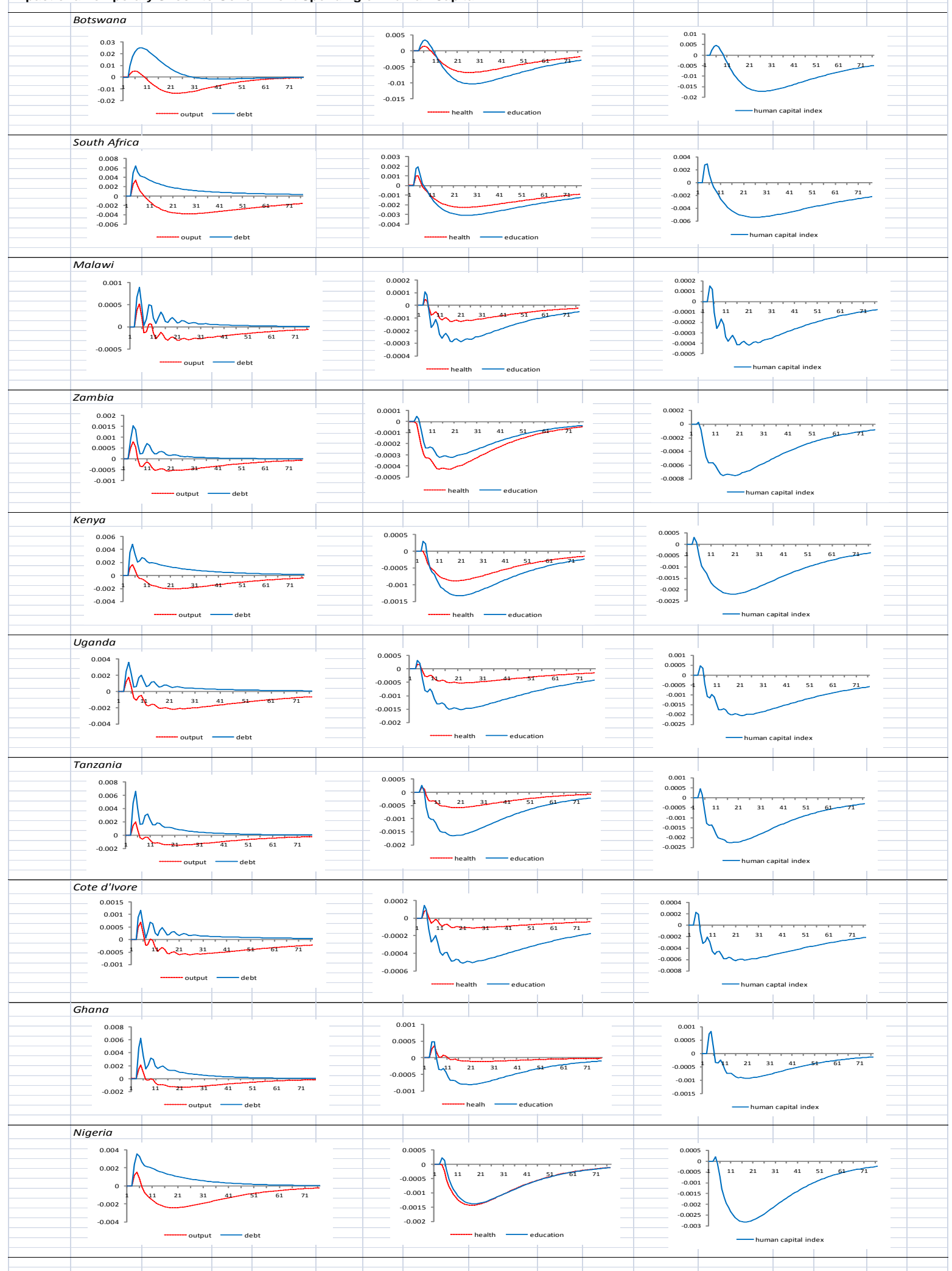


Figure 6: Impact of a 1\% Permanent Shock to Government Spending on Health and Education (total effect)

Impact of a Permanent Shock to Government Spending on Human Capital

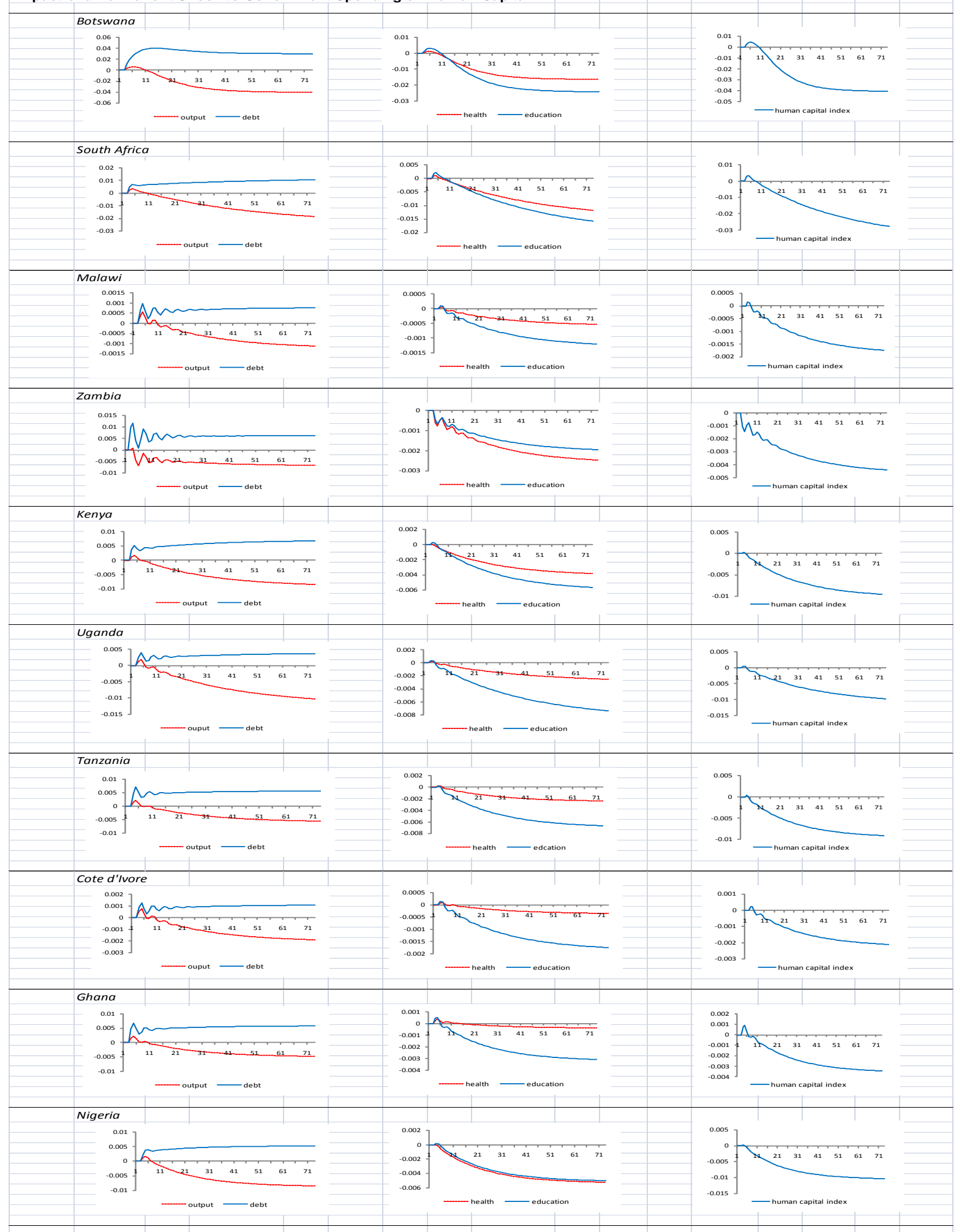


Our findings reveal that the impact of a shock to government spending on health and education is more positively pronounced for countries which allocate a higher proportion of government expenditure to the health and education sectors. This is evident in the case of Botswana and South Africa where expenditure on education sectors averages $20 \%$ of the sectoral allocations where this strategy has contributed significantly to human capital development. For countries such as Zambia and Nigeria, only about $5 \%$ and $10 \%$ on average is allocated to government spending on the health and education sector respectively, we find that the impact effect of a positive shock to government spending in these two countries is found to be of a lesser magnitude. Government expenditure is therefore key in the development of human capital although the without sufficient resources to back expenditure increases, raising expenditure in some countries to develop human capital is a constraint as demonstrated by varying fiscal commitments and high debt to GDP ratios which impact negatively on output growth. This is clear from the rise in the public debt as government expenditure increases permanently, demonstrating fiscal challenges which constrain the development and growth path with the result fact that some countries may not develop human capital solely on the strength of domestic resources.

Although results for Botswana and South Africa show that government expenditure can play a role in growth and developing human capital, it is also clear that as public expenditure rises, public debt and deficit could rise substantially as well. This brings in the sustainability of resource commitments to human capital development and resources to back growth in spending outlays versus revenue outlays as captured elements of the GBC in the dynamic system. Compared to other countries such as Zambia, Malawi, Uganda and Tanzania, the proportions of government spending allocated to health and education in the national budget averages less than $10 \%$ while in the case of Botswana and South Africa, the allocation averages about $20 \%$. As such, a permanent shock to government spending on health and education has a significant and pronounced impact on public debt in Botswana and South Africa. This is consistent in the case of Botswana where the country commits high resources due to health problems that affected the country since the 1990,s particularly the HIV/AIDS pandemic with government provide free education and HIV/AIDS treatment. South Africa has developed education and health infrastructure which has been enabled by the high proportion of government and private sector resources committed over years to their development.

The results also show that countries with lower human capital and those that are committing less resources in the form of government spending would have to channel more resources in the health and education sectors to realize significant human capital development and further growth. This would be a challenge given the reaction of the public debt which is more pronounced and indicative of how fiscal challenges would also impact on the development of human capital given limited fiscal spaces in countries where the public debt is high and government expenditure is already without room for expansion. These findings show that countries without the fiscal space and flexibility to raise government revenue and expenditure would be constrained in developing human capital and achieving more sustainable growth without a funding support mechanism. In this regard, such countries would not be able to develop human capital solely on the strength of their own domestic resources. Studies by Cashin (1995), Bose et al. (2003) and Aizeman et al. (2007) find support for the positive role of government spending on growth but also underscore the importance of constraints such as on revenues and sources which limit resource allocation to important priority sectors in developing countries to ensure sustained growth.

\section{Conclusion}

We conclude that an increase in the public debt impacts negatively on human capital development and growth especially beyond the $30-40 \%$ GDP threshold. This is because public debt takes away resources through debt service and thus limits government resources that can be allocated for development projects and social spending such as on health and education. The impact of the public debt on the human capital index which is composed of health and education is found to be negatively affected by the public debt in the selected countries. In all cases, it is clear that the impact of the public debt in the case of Botswana and South Africa where the public debt/GDP ratio has been maintained at levels below $40 \%$, the impact effect on human capital, the deficit and government spending is less pronounced. In other countries, however, where the debt to GDP ratio has exceeded $40 \%$ of GDP on average (for example in countries such as Zambia, Malawi, Cote d'Ivore, Tanzania, Uganda), the impact of the debt is found to lead to significant declines in output, human 
capital and government expenditure while the deficit rises substantially. This is observed in Zambia, Malawi, Tanzania, Uganda and Cote d'Ivore which have a one point been categorized as highly indebted poor countries.

The policy implication underscores the need to for debt management strategies that will ensure that countries maintain debt to GDP ratios at proportions that are not detrimental to the growth and human capital development initiatives particularly beyond the $30-40 \%$ debt to GDP threshold. It is clear that countries that already face high debt and fiscal constraints may not be in a position to develop human capital solely based on the strength of their domestic resources. Besides, the efforts to deal with the public debt, such as the HIPC and multilateral debt relief initiatives, it is important to have a fund that targets human capital development specifically, focusing on health and education in developing countries as key elements of human capital given their positive role on labour effectiveness, productivity and growth. This would go a long way in ensuring that some of the objectives and targets of the MGDs are realized. More importantly, the development of human capital will result in the long term sustained growth that is required by developing countries. Effective human capital development strategies are key to unleashing the growth potential and attaining efficiency, productivity and competitiveness leading to sustainable growth. While we conclude that government expenditure increase is found to have a positive role on health and education. The effect is generally positive and more pronounced for countries which allocate a higher proportion of government expenditure to the health and education sectors though sustainability becomes questionable. This is evident in the case of Botswana and South Africa where expenditure on education sectors averages $20 \%$ of the sectoral allocations. For countries such as Zambia, Cote d'Ivore and Malawi, Uganda and Tanzania, only an average of $10 \%$ and less is allocated to government spending on the health and education sector respectively. The impact effect of a shock to government spending in these countries is found to be of a lesser magnitude, though still positive. As such, a permanent shock to government spending on health and education has a significant and pronounced impact on public debt in Botswana and South Africa.

This is an interesting finding and result since the indications is that the higher the resources committed to health and education, the greater the impact on output growth and development of human capital. This also shows that countries with lower human capital and those that are committing less resources in the form of government spending would have to channel more resources in the health and education sectors to realize significant human capital development and further growth. However, with the government budget constraint in the model dynamics, our findings show that countries without the fiscal space and flexibility to raise government revenue and expenditure would be constrained in developing human capital and achieving more sustainable growth. This finding indicates that with the recent financial crisis of 2007/08 where most countries face high public debts and government expenditure constraints, and as such channeling resources to key developmental programs for human capital development and growth in general would be a challenge. In this case, these countries would not be able to develop human capital solely on the strength of their own domestic resources and strength. It therefore becomes key to address constraints on the elements of the GBC mainly the revenues generation elements and promoting efficient resource allocation mechanisms that would prioritize sectors and activities in developing countries to ensure sustained growth.

Acknowledgements: I am grateful to the support and funding from African Economic Research Consortium (AERC), the African Capacity Building Foundation and the Botswana Institute for Development Policy Analysis (BIDPA). I wish to thank Prof. Christopher Malikane for the guidance and comments which shaped this paper. I am also thankful to all the reviewers of the paper whose comments served to enhance the quality of the paper till completion.

\section{References}

Aizenman, J., Kletzer, K. \& Pinto, B. (2007). Economic Growth with Constraints on Tax Revenues and Public Debt: Implications for Fiscal Policy and Cross-Country Differences National Bureau of Economic Research Working Paper 127501050 Massachusetts Avenue Cambridge, MA 02138

Barro, R. J. (1990). Government Spending in a Simple Model of Endogenous Growth. Journal of Political Economy, 98(5), S103-S125. 
Barro, R. J. (1991). Economic Growth in a Cross Section of Countries. Quarterly Journal of Economics, CVI, $407-$ 444.

Barro, R. J. \& Lee, J. W. (1993). International Comparisons of Educational Attainment. Journal of Monetary Economics, 32(3), 363-94.

Barro, R. J. \& Sala-i-Martin, X. (1990). Public Finance in Models of Economic Growth, NBER Working Papers 3362, National Bureau of Economic Research, Inc.

Barro, R. J. \& Sala-i-Martin, X. (1995). Economic Growth", McGraw-Hill, Boston, Massachusetts.

Bigsten, A., Jörgen Levin, J. \& Persson, H. (2001). Debt Relief and Growth: A Study of Zambia and Tanzania. Prepared for the WIDER Development Conference on Debt Relief, Helsinki, 17-18 August 2001.

Bose, N., Haque, E. M. \& Osborn, D. R. (2003). Public Expenditure and Economic Growth: A Disaggregated Analysis for Developing Countries Centre for Growth and Business Cycle Research, School of Economic Studies, University of Manchester, Manchester, M13 9PL, UK.

Bils, M. \& Peter, K. J. (1998). Does Schooling Cause Growth or the Other Way Around? National Bureau of Economic Research Working Paper No. 6393, Cambridge, MA.

Benhabib, J. \& Spiegel, M. (1997). Growth and Investment Across Countries: Are Primitives All that Matter? Working Papers in Applied Economic Theory 97-03, Federal Reserve Bank of San Francisco

Bloom, D. E., Canning, D. \& Sevilla, J. (2004). The Effect of Health on Economic Growth: A Production Function Approach. World Development, 32(1), 1-13.

Blinder, A. S. \& Solow, R. M. (1973). Does fiscal policy matter? Journal of Public Economics, 2, 319-338.

Caselli, F., Esquivel, G. \& Lefort, F. (1996). Reopening the convergence debate: a new look at cross country growth empirics. Journal of Economic Growth, 1, 363-389.

Cashin, P. (1995). Government Spending, Taxes, and Economic Growth. IMF Staff Papers, 42(2), 237 - 269.

Christ, C. F. (1967). A short-run aggregate-demand model of the interdependence and effects of monetary and fiscal policies with Keynesian and classical interest elasticities. American Economic Review, 57, 434-443.

Christ, C. F. (1968). A simple macroeconomic model with a government budget restraint. Journal of Political Economy, 76, 63-67.

Christ, C. (1979). On Fiscal and Monetary Policies and the Government Budget Constraint. American Economic Review, 69, 526-38.

Christopher, A. S. (1995). Econometric Implications of the Government Budget Constraint. Journal of Econometrics, 83(1), 9-19(11).

Chowdhury, A. R. (2001). External Debt and Growth in Developing Countries: A Sensitivity and Causal Analysis. WIDER Discussion Paper No. 2001/95, United Nations University.

Clements, B., Bhattacharya, R. \& Nguyen, T. Q. (2003). External Debt, Public Investment, and Growth in LowIncome Countries. IMF Working Paper WP/03/249, Washington, DC.

Easterly, W. \& Rebelo, S. (1993). Fiscal Policy and Economic Growth: An Empirical Investigation. Journal of Monetary Economics, 32, 417-458.

Easterly, W. R. \& Levine, R. (1997). Africa's Growth Tragedy: Policies and Ethnic Divisions. Quarterly Journal of Economics, 112, 1203-1250.

Elbadawi, I. A., Ndulu, B. J. \& Ndung'u, N. (1997). Debt Overhang and Economic Growth in Sub-Saharan Africa, Chapter 5 in External Finance for Low-Income Countries, ed. by Zubair Iqbal and Ravi Kanbur (Washington: International Monetary Fund).

Greiner, A., Semmler, W. \& Gong, G. (2004). Economic Growth: A Time Series Perspective. International Monetary Fund and World Bank. Washington DC.

Greiner, A. (2008). Human capital formation, public debt and economic growth. Journal of Macroeconomics, 30(1), 415-427.

King, R. \& Rebelo, S. (1990). Public Policy and Economic Growth: Developing Neoclassical Implications. Journal of Political Economy, 98, 126-150.

Kneller, R., Bleany, M. F. \& Gemmell, N. (1999). Fiscal Policy and Growth: Evidence from OECD Countries. Journal of Public Economics, 74, 171 - 190.

Limam, Y. R. \& Miller, S. M. (2004). Explaining Economic Growth: Factor Accumulation, Total Factor Productivity Growth, and Production Efficiency Improvement. Economics Working Papers. Paper 200420.

Levine, R. \& Renelt, D. (1992). A Sensivity Analysis of Cross-Country Growth Regressions. American Economic Review, 82(4), 942-963. 
Mankiw, N. G., Romer, D. \& Weil, D. N. (1992). A Contribution to the Empirics of Economic Growth. Quarterly Journal of Economics, 107(2), 407-437.

Pattillo, C., Helene, P. \& Ricci, L. (2004). What Are the Channels Through Which External Debt Affects Growth? IMF Working Paper WP/04/15, Washington, DC.

Pattillo, C., Hélène, P. \& Ricci, L. (2002). External Debt and Growth, IMF Working Paper 02/69. Washington DC.

Romer, P. M. (1990). Human Capital and Growth: Theory and Evidence. Carnegie-Rochester Conference Series on Public Policy, 32, 251-286.

Strauss, J. \& Thomas, D. (1998). Health, nutrition, and economic development. Journal of Economic Literature, $36,766-817$.

Sachs, J. D. (1986). The Debt Overhang of Developing Countries, in Calvo, Guillermo et al., Debt, Stabilization, and Development: Essays in Memory of Carlos Diaz-Alejandro, 80-102.

Sachs, J. D. (1989). Developing Country Debt and the World Economy. Chicago: NBER University of Chicago Press.

Solow, R. (1956). A contribution to the theory of economic growth. Quarterly Journal of Eco omics, 70, 65-94.

Turnovsky, S. J. (1975). The Dynamics of Fiscal Policy in an open economy. Journal of International Economics, $6,115-142$

World Bank (2011). World Development Report, World Bank, Oxford University Press, 2011. 
Appendix: Derivations of Equations

Reduced from of $\boldsymbol{y}_{\boldsymbol{t}}$ :

$\tilde{Y}_{t}=A_{0 t}{ }^{1-\propto}\left[h_{t}^{\gamma} e_{t}^{1-\gamma}\right]^{1-\alpha}\left[\omega_{y} \widetilde{K}_{t}\right]^{\alpha}\left[1-v_{e}-v_{h}\right] G^{\mu}$

$X_{t} /_{A_{o t}}=$ per capita, $\widehat{x_{t}}$

$\tilde{y}_{t}=\left[h_{t}^{\gamma} e_{t}^{1-\gamma}\right]^{1-\alpha}\left[\omega_{y} k_{t}\right]^{\alpha}\left[1-v_{e}-v_{h}\right] g^{\mu}$

$y_{t}=h_{0}^{\gamma(1-\alpha)} \omega_{h}^{\beta_{h} \gamma(1-\alpha)} h_{t}^{\beta_{h} \gamma(1-\alpha)} v_{h}^{\chi_{h}(1-\alpha)} g^{\chi_{h}(1-\alpha)} \cdot e_{0}{ }^{(1-\gamma)(1-\alpha)}$

$\omega_{e}^{\beta_{e}(1-\gamma)(1-\alpha)} h_{t}^{\beta_{e}(1-\gamma)(1-\alpha)} \alpha$.

$v_{e}{ }^{\chi_{e}(1-\alpha)} g^{\chi_{e}(1-\alpha)} \cdot \omega_{y}{ }^{\alpha} k_{t}{ }^{\alpha} \cdot\left(1-v_{e}-v_{h}\right) g^{\mu}$

where:

$\theta=\alpha+\beta_{h} \gamma(1-\alpha)+\beta_{e}(1-\gamma)(1-\alpha)$

$\phi=1-v_{e}-v_{h} ; \Omega=h_{0}^{\gamma} e_{0}^{1-\gamma}$

$v=v_{h} \chi_{h} \gamma(1-\alpha) v_{e} \chi_{e}(1-\gamma)(1-\alpha)$

$\omega=\omega_{h}^{\beta_{h} \gamma(1-\alpha)} \omega_{e}{ }^{\beta_{e}(1-\gamma)(1-\alpha)} \omega_{y}{ }^{\alpha}$,

$y_{t}=\Omega_{0}{ }^{(1-\alpha)} \omega k_{t}{ }^{\theta} v \phi^{\mu} g$

Capital accumulation constraint $\dot{k}$

$Y=C+I+G+r B$

$I=Y-C-G-r B$

$\dot{K}=I-\delta K$

$\dot{K}=Y-C-G-\partial K-r B$

$\frac{\dot{K}_{t}}{A_{0 t} L_{t}}=-\frac{\delta K_{t}}{A_{0} L_{t}}+\frac{Y_{t}}{A_{0} L_{t}}-\frac{C_{t}}{A_{0} L_{t}}-\frac{r_{t} B_{t}}{A_{0} L_{t}}$

$\frac{\dot{K}_{t}}{A_{0 t} L_{t}}=-\delta k_{t}+y_{t}-c_{t}-r_{t} b_{t}$

$\dot{k}_{t}=\frac{\dot{K}_{t} A_{0 t} L_{t}-\dot{A}_{0 t} L_{t} K_{t}-\dot{L}_{t} A_{0 t} K_{t}}{A_{0 t} L_{t}{ }^{2}}$

$\dot{k_{t}}=\frac{\dot{K_{t}}}{A_{0 t} L_{t}}-\frac{\dot{A_{0 t}}}{A_{t}} k_{t}-\frac{\dot{L_{t}}}{L} k_{t}$

$\dot{k_{t}}=\frac{\dot{K}_{t}}{A_{0 t} L_{t}}-\varphi k_{t}-n k_{t}$

$\dot{k}_{t}+g k_{t}-\varphi k_{t}=-(\partial+\varphi+n) k_{t}$

$\dot{k}=y_{t}-c_{t}-g_{t}-r_{t} b_{t}-(\partial+n+\varphi)$

$M P K=r=\frac{\partial y}{\partial k}=\Omega_{0}{ }^{1-\alpha} \omega \theta k^{\theta-1} v \phi^{\mu} g$

$\dot{k}=\Omega_{0}{ }^{(1-\alpha)} \omega k_{t}{ }^{\theta} v \phi^{\mu} g-c_{t}-g_{t}-\left(\Omega_{0}{ }^{1-\alpha} \omega \theta k^{\theta-1} v \phi^{\mu} g\right) b_{t}-$ $(\partial+n+\varphi)$

Government Budget Constraint $\dot{b}$

$b=B_{t} / A_{0 t} L_{t}$

$b=\dot{B} L-\dot{L} B-A L B / A^{2} L^{2}{ }^{910}$

$\frac{\dot{B}}{L}-\frac{\dot{L}}{L} b-\varphi b$

$\dot{b}+n b+\varphi b=\frac{\dot{B}}{L}$

$\dot{b}+n b+\varphi b=g-t-r b$

$\dot{b}=g-t+(r-n-\varphi) b$

$\dot{b}=g-\tau y+(r-n-\varphi) b$

$\left.b=g-\tau\left(\Omega_{0}{ }^{1-\alpha} \omega k^{\theta} v \phi^{\mu} g\right)+\left(\Omega_{0}{ }^{1-\alpha} \omega \theta k^{\theta-1} v \phi^{\mu} g\right)-n-\varphi\right) b$

Optimization and first order conditions to derive $\dot{c} / c$

Maximize :

$$
\begin{aligned}
\int_{0}^{\infty} e^{p t} \frac{\check{C}_{t}^{1-\sigma}}{1-\sigma} d t=\int_{0}^{\infty} e^{p t} A_{0 t}^{1-\sigma} \frac{\check{C}_{t}^{1-\sigma}}{1-\sigma} d t \\
=\int_{0}^{\infty} e^{(\varphi(1-\sigma)-p) t} \frac{\check{C}^{1-\sigma}}{1-\sigma} d t
\end{aligned}
$$

Subject to:

$\dot{k}_{t}=\Omega_{0}^{1-\alpha} \omega k_{t}^{\theta} v \phi^{\mu} g-c_{t}-g_{t}-\Omega_{0}^{1-\alpha} \omega \theta k_{t}^{\theta-1} v \phi^{\mu} g b_{t}-$

$(\delta+n+\varphi) k_{t}$

And:

$\dot{b}=g-\tau\left(\Omega_{0}^{1-\alpha} \omega k_{t}^{\theta} v \phi^{\mu} g\right)+\left(\Omega_{0}^{1-\alpha} \omega \theta k_{t}^{\theta-1} v \phi^{\mu} g\right) b_{t}$

The Hamiltonian $\mathrm{H}$ :

${ }^{9} t$ subscripts for all variables relevant, just as is the case in the derivation of $k(t)$

10
$H=$

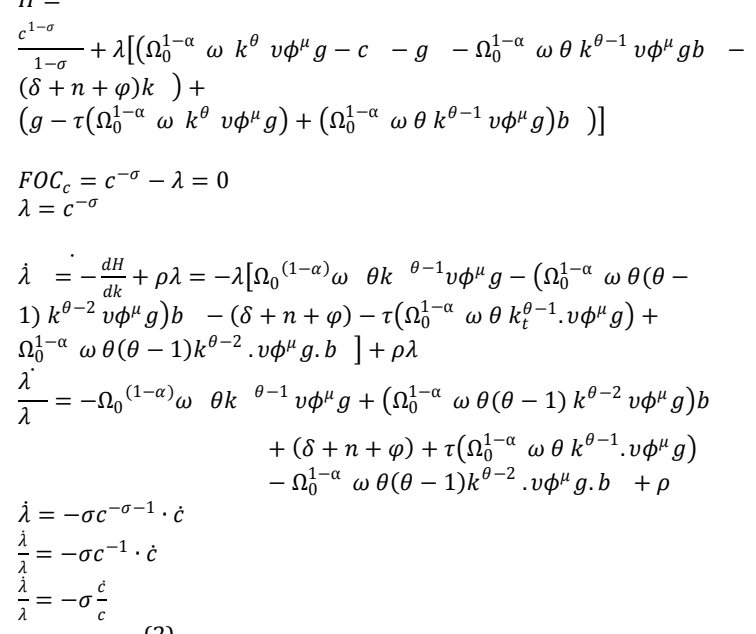

Equating equation 1 and 2 :

$$
\begin{aligned}
& -\sigma \frac{\dot{c}}{c}=-\Omega_{0}{ }^{(1-\alpha)} \omega \quad \theta k^{\theta-1} v \phi^{\mu} g+\left(\Omega_{0}^{1-\alpha} \omega \theta(\theta-1) k^{\theta-2} v \phi^{\mu} g\right) b \\
& +(\delta+n+\varphi)+\tau\left(\Omega_{0}^{1-\alpha} \omega \theta k^{\theta-1} \cdot v \phi^{\mu} g\right) \\
& -\Omega_{0}^{1-\alpha} \omega \theta(\theta-1) k^{\theta-2} v . \phi^{\mu} g . b+\rho \\
& \Omega_{0}{ }^{(1-\alpha)} \omega \quad \theta k^{\theta-1} v \phi^{\mu} g-\left(\Omega_{0}^{1-\alpha} \omega \theta(\theta-1) k^{\theta-2} v \phi^{\mu} g\right) b- \\
& (\delta+n+\varphi) \\
& \frac{\dot{c}}{c}=\frac{-\tau\left(\Omega_{0}^{1-\alpha} \omega \theta k^{\theta-1} \cdot v \phi^{\mu} g\right)+\left(\Omega_{0}^{1-\alpha} \omega \theta(\theta-1) k^{\theta-2} \cdot \phi^{\mu} g\right) \cdot b-\rho}{\sigma} \\
& \frac{\dot{c}}{c}=\frac{(1-\tau) \Omega_{0}{ }^{(1-\alpha)} \omega \quad \theta k^{\theta-1} v \phi^{\mu} g-(\delta+n+\varphi)-\rho}{\sigma}
\end{aligned}
$$


Appendix: Summary Tables of Diagnostic Statistics

Summary Diagnostic Statistics for the Estimated Equations of the Model

\begin{tabular}{|c|c|c|c|c|c|c|c|c|c|c|}
\hline \multicolumn{11}{|c|}{ Summary Statistics for the Estimated Equations of the Model } \\
\hline & Botswana & South Africa & Malawi & Zambia & Kenya & Tanzania & Uganda & Cote d'Ivore & Ghana & Nigeria \\
\hline \multicolumn{11}{|l|}{ Equation 1 (Production Function) } \\
\hline $\begin{array}{r}\text { Adj. R-squared } \\
\text { F Statitistic }\end{array}$ & $\begin{array}{c}0.9721 \\
163.8600\end{array}$ & $\begin{array}{c}0.9763 \\
372.6300\end{array}$ & $\begin{array}{c}0.9742 \\
246.9400\end{array}$ & $\begin{array}{l}0.9437 \\
114.1900\end{array}$ & $\begin{array}{c}0.9922 \\
1147.9200\end{array}$ & $\begin{array}{c}0.9783 \\
287.4600\end{array}$ & $\begin{array}{c}0.9923 \\
1162.0000\end{array}$ & $\begin{array}{c}0.9566 \\
100.3500\end{array}$ & $\begin{array}{c}0.9479 \\
78.0600\end{array}$ & $\begin{array}{c}0.9110 \\
70.1000\end{array}$ \\
\hline Prob (F-Statistic) & 0.0000 & 0.0000 & 0.0000 & 0.0000 & & 0.0000 & & & 0.0000 & 0.0000 \\
\hline \multicolumn{11}{|l|}{ Equation 2 (Labour Effectiveness) } \\
\hline $\begin{array}{r}\text { Adj. R-squared } \\
\text { F Statitistic }\end{array}$ & $\begin{array}{l}0.8944 \\
56.2900\end{array}$ & $\begin{array}{l}0.9256 \\
60.2700\end{array}$ & $\begin{array}{l}0.6532 \\
86.8200\end{array}$ & $\begin{array}{c}0.7934 \\
112.4600\end{array}$ & $\begin{array}{l}0.8756 \\
97.3200\end{array}$ & $\begin{array}{c}0.8292 \\
127.4900\end{array}$ & $\begin{array}{c}0.7932 \\
156.0200\end{array}$ & $\begin{array}{l}0.6844 \\
179.0700\end{array}$ & $\begin{array}{c}0.7209 \\
106.0500\end{array}$ & $\begin{array}{c}0.7902 \\
129.3600\end{array}$ \\
\hline Prob (F-Statistic) & 0.0000 & 0.0000 & 0.0000 & & 0.0000 & & 0.0000 & 0.0000 & 0.0000 & \\
\hline \multicolumn{11}{|l|}{ Equation 3 (Education Equation) } \\
\hline Adj. R-squared & 0.9430 & 0.9538 & 0.9634 & 0.9202 & 0.9742 & 0.9813 & 0.9855 & 0.9649 & 0.9547 & \\
\hline $\begin{array}{r}\text { F Statitistic } \\
\text { Prob (F-Statistic) }\end{array}$ & 67.3190 & $\begin{array}{c}140.5100 \\
0.0000\end{array}$ & $\begin{array}{c}178.8800 \\
0.0000\end{array}$ & $\begin{array}{c}78.9000 \\
0.0000\end{array}$ & 341.8600 & $\begin{array}{c}335.0600 \\
0.0000\end{array}$ & $\begin{array}{c}368.8600 \\
0.0000\end{array}$ & $\begin{array}{c}187.0800 \\
0.0000\end{array}$ & 190.9600 & 169.0900 \\
\hline \multirow{2}{*}{\multicolumn{11}{|c|}{ Equation 4 (Health Equation) }} \\
\hline & & & & & & & & & & \\
\hline F Statitistic & 140.7000 & 138.3100 & 118.5400 & 74.0500 & 458.0800 & 121.7900 & 258.8800 & 297.3000 & 211.1200 & 91.9800 \\
\hline Prob (F-Statistic) & 0.0000 & 0.0000 & 0.0000 & 0.0000 & & 0.0000 & 0.0000 & 0.0000 & 0.0000 & 0.0000 \\
\hline
\end{tabular}

Summary Results for Endogeniety Tests

Extent of Endogeneity Problem : Hausman Test Results

Dependent Variable: Measure of Labour effectiveness/Productivity

Variables Tested

Test Statistic (df)

Health , Education

1.89 (1)

Health

1.45 (1)

Variables Tested

Test Statistic (df)

Dependent Variable: Education

Variable tested

Health

1.61 (1)

Education

1. $73(1)$

Education, Health

$5.69(2)$

Education, Health

4.37 (2)

Education, Health

5.02 (2)

Dependent Variable: Health

Variables Tested

Test Statistic (df)

Education, Health

4.91 (2) 